\title{
ДИНАМИКА ЗЕМЛЕПОЛЬЗОВАНИЯ СУЬЪЕКТА ФЕДЕРАЦИИ
}

Мазуркин П.М., д.т.н., проф., акад. РАЕ и РАЕН, член ЕАЕ, Поволжский ГТУ, Йошкар-Ола, пл. Ленина, 3, kaf_po@mail.ru

Введение. Изменения в земельном кадастре РМЭ учитывались три раза: вначале был период 1985-1999 гг. [2, 4], второй раз 1985-2005 гг. [8, 9]. В статье [5] дается третья итерация по динамическому ряду 1985-2012 гг.

Методология факторного анализа изложена в [1, 3, 6-10].

Цель статьи - показать метод анализа динамики площади земель по категории кадастра. Наш факторный анализ отличается от известных подходов: каждый фактор производства (в нашем случае категория земель) принимается за независимую физическую величину, а затем ищутся факторные связи между ними.

Исходные данные. По ежегодным уточнениям земельного кадастра табличная модель (табл. 1) была подготовлена в Управлении Росреестра по РМЭ. Оказалось, что сопоставление идет только с предыдущим годом, а по прошлым годам доклады сдаются в архив. Такая ситуация наблюдается во всех субъектах федерации. Поэтому нужно обобщение по всем прошлым годам.

В 2002-2003 гг. произошел скачок в регистрации данных и переход на дату первое января следующего года. Поэтому до конца 2012 г. уже известно распределение земель по категориям. При этом общая площадь РМЭ за период 1985-2012 гг. не изменялась и равна 2337,5 тыс. га.

Далее в статье рассмотрим земли только 1 категории - земли сельскохозяйственного назначения.

Динамичность покажем по тренду (тенденции) в виде экспоненциального закона гибели (рис. 1) по формуле

$$
S=921,9552 \exp \left(-0,068021 t^{0,14236}\right),
$$

где $S$ - площадь земель сельскохозяйственного назначения, тыс. га, $t$ - время с начала учета земель в РМЭ ( $t=0$ для 1985 г.), лет.

Коэффициент корреляции 0,457 находится в интервале 0,30,5 слабой тесноты связи. Однако фактические значения (точки около линии) имеют сильное колебание. 


\begin{tabular}{|c|c|c|c|c|c|c|c|c|}
\hline \multicolumn{9}{|c|}{$\begin{array}{c}\text { Таблица } 1 \\
\text { Динамика распределение земельного фонда РМЭ } \\
\text { по категориям земельного кадастра, тыс. га } \\
\end{array}$} \\
\hline \multirow{2}{*}{$\begin{array}{c}\text { Год } \\
\text { учета }\end{array}$} & \multirow{2}{*}{$\begin{array}{c}\text { Время } \\
t, \text { лет }\end{array}$} & \multicolumn{7}{|c|}{ Категория земель по кадастру } \\
\hline & & 1 & 2 & 3 & 4 & 5 & 6 & 7 \\
\hline 1985 & 0 & 922,0 & & & 0.0 & & 0.6 & \\
\hline 19 & 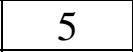 & & & & 36.2 & & 0.5 & 89.8 \\
\hline & & & & & & & 90.0 & \\
\hline 199 & 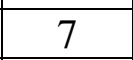 & & & & & & 90.0 & \\
\hline & - & & & 73.2 & & & 65.1 & \\
\hline & & & & & & & 64.6 & \\
\hline & & & & & & & 64.6 & \\
\hline 19 & & & 14 & 70.9 & 58.2 & & 63.1 & .1 \\
\hline & & & & 6 & & & 64.8 & \\
\hline & & & & & & & 64.8 & \\
\hline & & & & & 58.2 & & 66.4 & \\
\hline & & & & 73.1 & 58.2 & & 67.0 & 5.3 \\
\hline & & & & 72 & 58.5 & & 67.0 & 6.2 \\
\hline \begin{tabular}{|c|}
$2002^{* *}$ \\
$*$
\end{tabular} & & 86 & & 7 & 58.5 & & 68.0 & 57 \\
\hline & & & & & & & 68.0 & \\
\hline & & 86 & 5 & 5 & 58.5 & & 68.0 & 4.9 \\
\hline 2005 & & & & 71 & 58.5 & & 67.6 & 5.0 \\
\hline & & 860,5 & 77.0 & 71.3 & 58.6 & & 67.6 & \\
\hline 2007 & & 860,3 & 77.1 & 71.4 & 58.6 & & 67.6 & 5.0 \\
\hline & & 853,5 & 80.8 & 71.3 & 58.6 & & 67.6 & 5.0 \\
\hline 2009 & - & 816,2 & 82.0 & 71.4 & 58.6 & \begin{tabular}{|l}
1236.7 \\
\end{tabular} & 67.6 & 5.0 \\
\hline 2010 & & 789,5 & 82.3 & 77.9 & 58.6 & 1256.6 & 67.6 & 5.0 \\
\hline 2011 & 2 & 779,8 & 82.5 & 77.9 & 58.6 & 1266.1 & 67.6 & 5.0 \\
\hline 2012 & 27 & 775,0 & 82.6 & 77.9 & 58.6 & 1270.8 & 67.6 & 5.0 \\
\hline
\end{tabular}

Примечания: * - год начала земельной реформы в республике; ** - год осуществления основных мероприятий земельной реформы; *** - начло отсчета данных измерений с 01.01 (с первого января); 1 - земли сельскохозяйственного назначения; 2 земли населенных пунктов; 3 - земли промышленности, транспорта, обороны и иного назначения; 4 - земли особо охраняемых территорий; 5 земли лесного фонда; 6 земли водного фонда; 7 земли запаса; внутри каждой категории земельного кадастра максимальные значения площади выделены полужирным шрифтом.

\section{Максимальное} значение площади сельхозугодий 924,3 тыс. га было в 1990 г., а минимальное значение продолжает уменьшаться дальше.

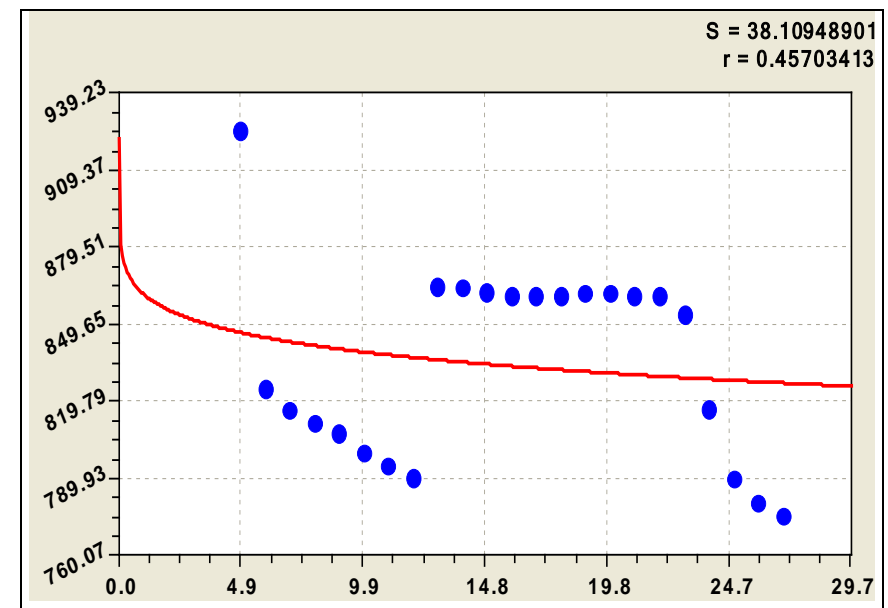

Рис. 1. Тренд (детерминированная модель) динамики земель РМЭ первой категории кадастра: абсцисса - время с 1985 года, лет; ордината площадь земель сельскохозяйственного назначения, тыс.га; в правом верхнем углу графика показываются дисперсия и коэффициент корреляции идентифицированной закономерности (1)

К 2012 г. произошло снижение на 149,3 тыс. га (или на 19,26\% к 2012 г.).

Коэффициент динамичности $K_{\text {д }}$ поведения системы управления первой земельной категорией за 28 лет определяется по формуле $K_{\partial}=100\left(S_{\phi}-S\right) / S$.

Наибольший остаток от формулы (1) равен $\varepsilon=S_{\phi}-S=$ 77,93 тыс. га (такая абсолютная погрешность равна площади сельского муници- 
палитета РМЭ), а коэффициент динамичности системы управления за 28 лет ведения земельного кадастра РМЭ составил 9,21\%.

Уменьшать амплитуду и успокаивать колебание. Опыт США с 1960 года и Китая с 1970 года убедительно показывает, что принудительный рост площади качественной растительности через 30 лет после передачи 30\% пашни под будущие леса позволяет получать валовой сбор зерновых даже больше, чем было при экстенсивном земледелии. Но в России залежи зарастают сорной растительностью, которая превратится в высококачественные леса только через 100-250 лет (так уже было в Европе в средние века после массового мора людского населения).

Таким образом, осознанное управление земельным фондом предполагает уменьшение амплитуды и частоты колебания всеми доступными мерами, прежде всего у площади земель первой категории, при условии достижения золотой пропорции с растительным покровом [2, 8, 10]. Тогда закон гибели (1) является естественным, а колебания вокруг неё зависят от поведения людей и поэтому показывают антропогенное воздействие.

Волновые закономерности. По остаткам от модели (1) были получены две макро волновые закономерности федерального поведения управленческой структуры (рис. 2).

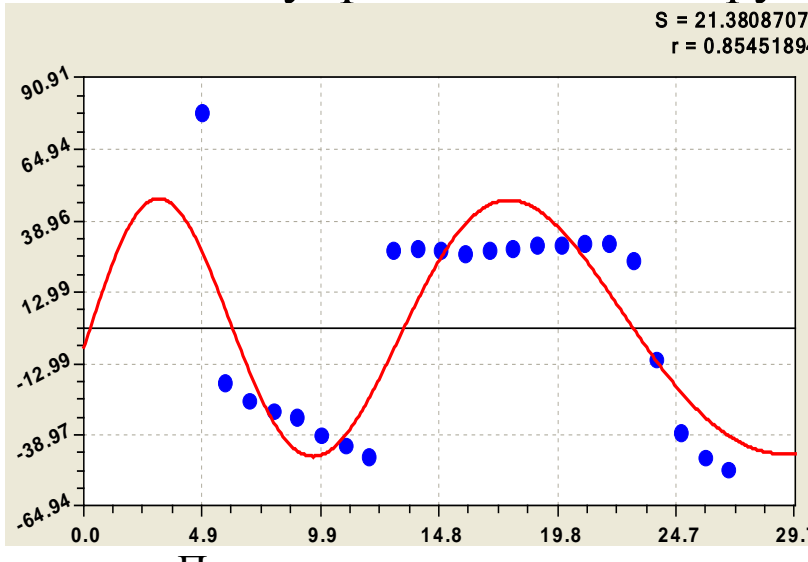

Первая волна возмущения

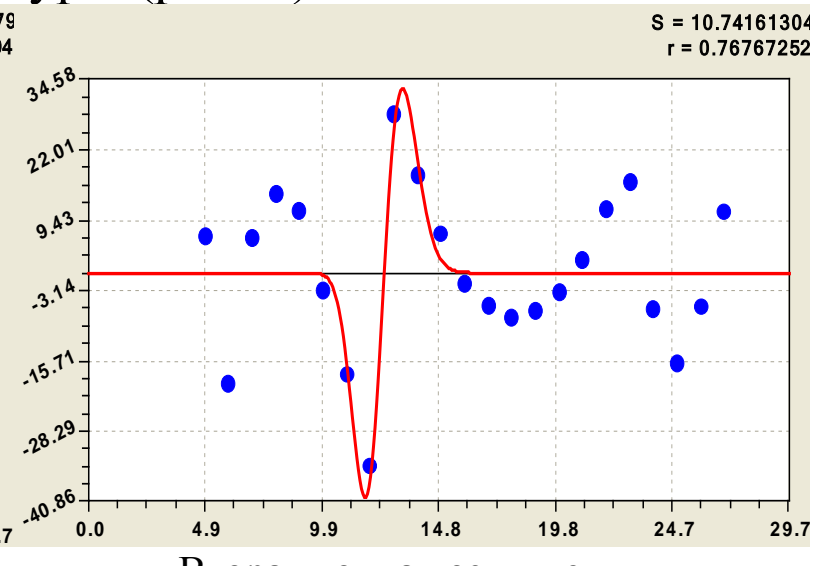

Вторая волна возмущения

Рис. 2. Графики волновых закономерностей антропогенного поведения в динамике площади земель сельскохозяйственного назначения

У первой волны амплитуда снижается медленно, а вторая волна является импульсной, соответствующей перетряске системы управления земельным фондом в 1995-1999 г. Обе волны имеют коэффициент корреляции выше 0,7 в интервале сильной тесноты связи 0,7-0,9 между изучаемыми факторами. 
Модель динамики сельхозугодий. После объединения трех составляющих была получена (рис. 3) общая статистическая модель в виде сложной биотехнической [1-10] закономерности

$$
\begin{aligned}
& \qquad=S_{1}+S_{2}+S_{3}, \\
& S_{1}=35009,0918 \exp \left(-2,16482 \cdot 10^{-5} t^{2,82582}\right), S_{2}=A_{1} \cos \left(\pi t / p_{1}-0,45367\right), \\
& A_{1}=-2868,2156 \exp (-0,0067106 t), p_{1}=0,56512+0,30037 t^{1,14849}, \\
& S_{3}=A_{2} \cos \left(\pi t / p_{2}-2,68114\right), A_{2}=2,98006 \cdot 10^{-136} t^{193,21686} \exp \left(-9,80424 t^{1,13010}\right), \\
& p_{2}=0,26816+0,020320 t^{1,34233},
\end{aligned}
$$

где: А - амплитуда (половина), тыс. га; p - полупериод, лет.

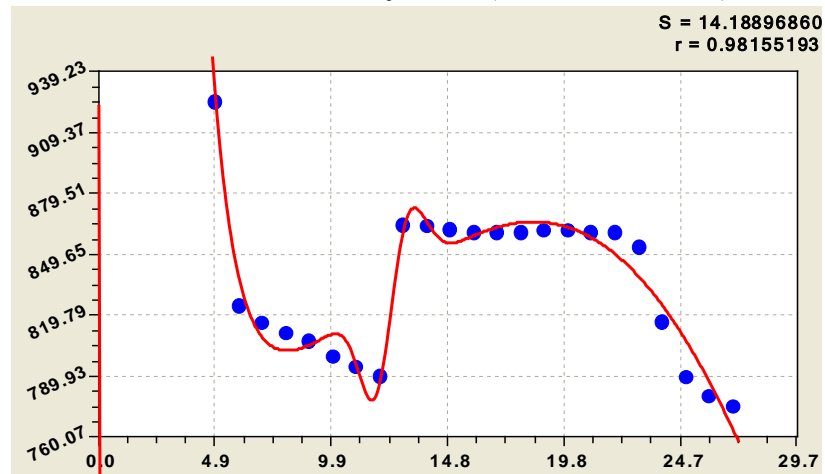

Рис. 3. Закономерность динамики площади земель сельскохозяйственного назначения
Коэффициент корреляции 0,9816 относит формулу (2) в сильнейшие закономерности. Анализ (2) показывает, что по первой составляющей до 1985 г. было физическое представление о бескрайних просторах отечественных земель. Этот вывод дает начальное значение 3500.0918 тыс. га по закону гибели (1), что больше площади РМЭ в 3500,0 / 2337,5 $\approx 1,5$ раза.

По кризисной второй составляющей (отрицательный знак) начальная амплитуда колебания физических представлений равна $2 \times(-2868.2156) \approx-5736,4$ тыс. га, что больше реальной площади республики в 5736,4 / 2337,5 $\approx 2,5$ раза. Так происходила ложная идентификация развития (экстенсивного) сельского хозяйства.

Вторую волну можно «списать», как все это делают, на системный социально-экономический кризис 90-х годов ХХ века. Но негативным является медленный спад амплитуды первой волны, а позитивным является повышение периода у обоих колебаний (процесс медленно успокаивается).

Начальный период был равным, соответственно, $2 \times 0.56512$ $\approx 1,13$ лет и $2 \times 0.26816 \approx 0,54$ года. Это очень быстрые процессы, трудно уловимые системе управления. Для экономики США характерны периоды колебаний в 17-20 лет и более. Тогда получается, что землеустройство РМЭ получило импульсное колебание в 90-х годах XX века с периодом в $17 / 0,54 \approx 31,5$ раз превышающей колебания американского сельского хозяйства. 
Волны федерально-регионального поведения. Каждый субъект федерации относится к земельному фонду по-своему, с учетом традиций и понимания местных землеустроителей. Такие и иные волны подробно показаны в статье [5].

По значению площади можно предложить следующую классификацию колебаний земель сельскохозяйственного назначения:

1) макроколебание с амплитудой более \pm 35 тыс. га, сравнимой с территорией среднего сельского муниципального образования на территории субъекта федерации;

2) мезоколебание с амплитудой \pm (1-35) тыс. га, сравнимой с территорией сельского фермера или сельхозпредприятия (в Финляндии в среднем фермер владеет 35 тыс. га);

3) микроколебание с амплитудой от цены деления 0,1 тыс. га по данным таблицы 1 (по точности \pm 50 га земельного кадастра) до \pm 1000 га, сравнимой с территорией крупных сельских товаропроизводителей, предприятий и организаций.

\section{Список литературы}

1. Арзамасцев А.Д., Мазуркин П.М., Максимец Н.В. Факторный анализ сельскохозяйственного производства. Йошкар-Ола: МарГТУ, 2009. 388 с.

2. Мазуркин П.М. Геоэкология: Закономерности современного естествознания. Йошкар-Ола: МарГТУ, 2006. 336 с.

3. Мазуркин П.М. Коррелятивная вариация: учеб. пос. с грифомУМО РАЕ. Йошкар-Ола: Поволжский ГТУ, 2013. 120 с.

4. Мазуркин П.М., Ильменев Г.Н., Салахутдинов Ф.Н. Закономерности кадастровой оценки сельскохозяйственных угодий (на примере Республики Марий Эл). Йошкар-Ола: МарГТУ-ФГУП МарГипрозем, 2002. 66 с.

5. Мазуркин П.М., Касьянов Ю.В. Динамика управления земельным фондом субъекта федерации // Регистрация - кадастр. 2012. № 2. С.16-22.

6. Мазуркин П.М., Михайлова С.И. Биотехническая оценка пойменного луга. М.: Изд-во «Академия естествознания», 2009. 279 с.

7. Мазуркин П.М., Михайлова С.И. Модели кадастровой оценки сельхозугодий // АПК: Экономика и управление. 2009. № 8. С.76-82.

8. Мазуркин П. М., Михайлова С.И. Территориальное экологическое равновесие $=$ Territprial ecological balance: аналит. обзор; Учреждение Рос. акад. наук Гос. публич. науч.-техн. б-ка Сиб. отд-ния РАН. Новосибирск: ГПНТБ СО РАН, 2010. 430 с. (Сер. Экология. Вып. 94).

9. Мазуркин П.М., Фадеев А.Н. Закономерности распределения земельного фонда (на примере РМЭ). Йошкар-Ола: МарГТУ, 2006. 127 с.

10. Михайлова С.И., Мазуркин П.М. Ландшафтно-экологическая роль пойменного луга малых рек. Йошкар-Ола: МарГТУ, 2011. 154 с. 